\title{
Low Temperature Biodisinfection Effectiveness for Phytophthora capsici Control of Protected Sweet Pepper Crops in the Southeast of Spain
}

\author{
María del Mar Guerrero ${ }^{1 *}$, Carmen $M^{a}$ Lacasa $^{1}$, Victoriano Martínez ${ }^{1}$, \\ $M^{a}$ Carmen Martínez ${ }^{1}$, Antonio Monserrat ${ }^{1}$ and Santiago Larregla ${ }^{2}$ \\ 1 Instituto Murciano de Investigación y Desarrollo Agrario y Alimentario, Dpto. Biotecnología y Protección de Cultivos, Murcia, \\ Spain, ${ }^{2}$ Plant Production and Protection Department, NEIKER-Basque Institute for Agricultural Research and Development, \\ Derio, Spain
}

OPEN ACCESS

Edited by:

Henrique Manuel da Fonseca

Trindade,

University of Trás-os-Montes and Alto

Douro, Portugal

Reviewed by:

Jose Antonio Pascual,

Consejo Superior de Investigaciones Cientificas (CSIC), Spain

Berta De Los Santos,

Centro IFAPA Las Torres

(CAPDER - JA), Spain

${ }^{*}$ Correspondence:

María del Mar Guerrero

mariam.guerrero@carm.es

Specialty section: This article was submitted to

Waste Management in

Agroecosystems,

a section of the journal

Frontiers in Sustainable Food Systems

Received: 27 January 2021 Accepted: 14 June 2021 Published: 14 July 2021

Citation:

Guerrero MM, Lacasa CM, Martínez V, Martínez MC, Monserrat A and Larregla S (2021) Low Temperature Biodisinfection Effectiveness for

Phytophthora capsici Control of Protected Sweet Pepper Crops in the Southeast of Spain. Front. Sustain. Food Syst. 5:659290. doi: 10.3389/fsufs.2021.659290
Biodisinfection using fresh sheep manure in August is effective in controlling Phytophthora root rot in greenhouses in southeast Spain, but this is not the case after the beginning of September. The effectiveness of biodisinfection of new amendments has been evaluated beginning in October in sweet pepper greenhouses to control Phytophthora capsici. The amendments used were: T1: wheat husk + fresh sheep manure (FSM), $3.5 \mathrm{~kg} \mathrm{~m}^{-2}$; T2: sunflower pellets $3.5 \mathrm{~kg} \mathrm{~m}^{-2}$; T3: FSM: $3.5 \mathrm{~kg} \mathrm{~m}^{-2}$; T4: Control. Temperatures above $40^{\circ} \mathrm{C}$ were obtained in some amendments; anoxic conditions were found in all amendments, and also a reduction of the viability of $P$. capsici oospores with respect to the control, as well as a higher yield. The contribution of fresh sheep manure to the amendments did not lead to an improvement in their effectiveness. Autumn biodisinfection under low temperature conditions using fresh organic amendments that enhance soil anaerobic conditions may be a promising strategy for the control of $P$. capsici in pepper greenhouses in southeastern Spain.

Keywords: soil disinfestation, Capsicum annuum, organic amendment, Phytophthora, oospores, greenhouse

\section{INTRODUCTION}

Greenhouses of pepper (Capsicum annuum L.) in southeast Spain suffer from serious economic losses caused by the oomycetes Phytophthora capsici and P. nicotianae, which contaminate most of the region's soils (Lacasa et al., 2013). Both of these oomycetes limit the crop, leading to important losses in plants and harvests if preventive measures are not adopted before planting (Lacasa et al., 2010; Guerrero et al., 2013). Nowadays, P. nicotianae is the most prevalent (Lacasa et al., 2013; Blaya et al., 2014), favored by the climatic conditions in the greenhouses and farming practices. Chlamydospores and/or oospores may survive for up to 6 years (Erwin and Ribeiro, 1996). The main soil-borne pathogens of protected peppers are Phytophthora spp. and Meloidogyne incognita in addition to soil fatigue issues which are specific of this crop. The previous soil phytopathological problems are both caused by the repeated growing of pepper crops in the same soil for over 30 years (Guerrero et al., 2014).

Between 1982 and 2005, soil disinfestation with methyl bromide was the way to palliate the effects of Phytophthora root rot in more than 95\% of the greenhouses (Lacasa et al., 2010). The mix 
of chloropicrin and 1,3-dichloropropene has replaced methyl bromide in over $70 \%$ of the surface area. Biodisinfection is used in $20 \%$ of the surface area, combining solarization with biofumigation (Lacasa et al., 2010; Guerrero et al., 2013).

The combination of solarization with biofumigation shows that the two methods have synergic effects (Katan, 2005). Sealing the soil with plastic produces the gas retention that occurs during organic matter decomposition (Bonanomi et al., 2007; Oka, 2010). If saturation levels are reached when the soil is wetted, then the effects of anaerobiosis are also added and phytoparasites and pathogens are affected (Blok et al., 2000).

If water saturation levels are not reached, but organic amendments containing a high carbon content are used anaerobiosis occurs under the plastic during biodecomposition (anaerobic soil disinfestation, ASD) which affects the pathogens (Shennan et al., 2014; Rosskopf et al., 2015). During the degradation process of the organic matter, changes occur in the composition of the microbiota that confer a suppressive character against some pathogens (Mazzola, 2011; NúñezZofío et al., 2011; Mazzola and Manici, 2012; Mazzola et al., 2012). The suppressive effects and the anaerobiosis depend on the soil characteristics, the organic amendment used, the soil temperature, the characteristics of the microbiota and the disinfectant effectiveness or the pathogens susceptibility (Butler et al., 2012, 2014). The choice of the organic matter used in the biodisinfection is one of the determining elements for its efficacy. Bonanomi et al. (2007) suggested that the application of specific organic matters: crop residues and organic wastes, compost and peat could be useful to increase soil suppressiveness. NúñezZofio et al. (2013), found an effective biofumigant in beetroot stillage. Guerrero et al. (2013), checked the effect of Brassica carinata pellets on Meloidogyne incognita in pepper greenhouses in southeast Spain.

European Union restrictions on the use of chemical products, as well as the increase in the surface area dedicated to ecological agriculture, require the use of soil organic amendments for soilborne disease management. Biodisinfection using fresh sheep manure in August gives good results in controlling Phytophthora in greenhouses in southeast Spain, although this is not the case when the process is performed after the start of September (Guerrero et al., 2010). The majority of the greenhouses soils in the region are clay loam (Haplocalcids), basic $\mathrm{pH}$, with an organic matter content between 1.5 and $2.5 \%$. The climate is Mediterranean with marine influence, hot dry summers, and mild winters. The greenhouse pepper crop is planted in December-January, and finishes in August-September.

In order to fit the start of the biodisinfection to the end of the cropping season it is necessary to commence in October. Using the amendments that are typically used in August (fresh sheep manure), the biodisinfection does not reduce the levels of pathogens, and are thus unviable (Guerrero et al., 2010, 2013; Lacasa et al., 2010), so it is necessary to improve the biodisinfection effects by adding amendments that strengthen the anaerobic effect or increase soil temperature, both effects by the organic matter decomposition.

Moreover, the southeast of Spain is in a vulnerable zone due to nitrates (Directive 91/676/CEE, of 12 December, relating to the protection of waters against contamination produced by agricultural origin nitrates) which means that there are restrictions on the contribution of nitrogen. This premise severely limits the use of organic matter in the zone.

The objective of this study was to obtain biodisinfection amendments that are effective in controlling Phythophthora in pepper greenhouses with low temperatures whilst also reducing the amount of fresh organic amendments.

\section{MATERIALS AND METHODS \\ Experimental Design and Treatments}

The field experiment was carried out over two crop seasons in an experimental sweet pepper greenhouse of $1,000 \mathrm{~m}^{2}$, at the experimental station of the IMIDA, located in the Campo de Cartagena, Region of Murcia (southeast Spain), where pepper has been grown periodically for over 20 years.

The clay loam soil was free from pathogens and was not previously disinfested.

The biodisinfection was performed in October for both seasons, starting on 2 October 2019 and 9 October 2020, respectively. Treatments were arranged in a randomized complete block design with four replicates and were repeated in the same plots in each of the two seasons. Each experimental unit consisted of a $60 \mathrm{~m}^{2}$ plot. The treatments evaluated were: T1: wheat husk (Alimer SCoop)+fresh sheep manure (WH+FSM) $3.5(2+1.5) \mathrm{kg} \mathrm{m}^{-2}$; T2: sunflower pellets (Alimer SCoop) (S) $3.5 \mathrm{~kg} \mathrm{~m}^{-2}$; T3: (FSM): $3.5 \mathrm{~kg} \mathrm{~m}^{-2}$; T4: Control (non-amended and non-covered with plastic). Amendments and the nonamended control soil treatment were analyzed in the 2 years (Table 1).

The amendments were applied and plots were rototilled to a depth of $25-30 \mathrm{~cm}$. The soil was irrigated using a drip irrigation system using $3 \mathrm{~L} \mathrm{~h}^{-1}$ emitters spaced $0.40 \times 0.60 \mathrm{~m}$ for $4 \mathrm{~h}$ on 2 consecutive days. Amended soil was covered with a $0.05 \mathrm{~mm}$ thick transparent polyethylene film. The plastic was maintained for 6 weeks. The "Beniel" (Syngenta Seeds) pepper cultivar was planted in December at the habitual density of the zone: $1 \mathrm{~m}$ separation between rows and $0.4 \mathrm{~m}$ between plants in the same row $\left(2.5\right.$ plants $\left.\mathrm{m}^{-2}\right)$.

\section{Inoculum Production}

The inoculum was obtained from a $P$. capsici isolate from pepper plants that presented symptoms and was conserved in the IMIDA mycology collection in PDA medium. When this isolate was inoculated into healthy pepper plants, it showed to be aggressive and maintained its pathogenicity. The isolate grew in controlled conditions at $25^{\circ} \mathrm{C}$ for 3 weeks until it reached the edge of a $9 \mathrm{~mm}$ diameter Petri dish. A micellar solution

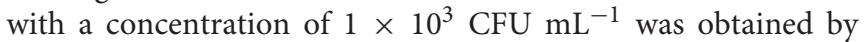
grinding the content of one dish in $100 \mathrm{~mL}$ of distilled sterile water and subsequent adjustment by dilution and direct count using a Neubauer counting chamber. A volume of $100 \mathrm{~mL}$ of soil, previously autoclaved at $120^{\circ} \mathrm{C}$ for $1 \mathrm{~h}$ on 2 consecutive days, was inoculated with $1 \mathrm{~mL}$ of micellar solution, and was placed inside muslin forming a bag. In three different points of each treatment 
TABLE 1 | Composition of organic amendments and non-amended control soil treatment.

\begin{tabular}{|c|c|c|c|c|}
\hline & Wheat husk & Sunflower pellets & Fresh sheep manures & Control \\
\hline Total OM \% & $91.3 \pm 22.1$ & $93.8 \pm 23.0$ & $52.23 \pm 3.92$ & $2.82 \pm 0.65$ \\
\hline Total $\mathrm{N} \mathrm{g} \mathrm{kg}^{-1}$ & $22.8 \pm 1.5$ & $48.5 \pm 2.3$ & $16.5 \pm 0.10$ & $0.7 \pm 0.39$ \\
\hline $\mathrm{C} / \mathrm{N}$ & $20.4 \pm 14.9$ & $11.5 \pm 14.1$ & $17.9 \pm 1.38$ & $9.54 \pm 0.81$ \\
\hline $\mathrm{P}_{2} \mathrm{O}_{5} \mathrm{~g} \mathrm{~kg}^{-1}$ & $25.2 \pm 01.1$ & $14.4 \pm 3.2$ & $0.95 \pm 0.03$ & $0,11 \pm 0.04$ \\
\hline $\mathrm{K}_{2} \mathrm{O} \mathrm{g} \mathrm{kg}{ }^{-1}$ & $20.1 \pm 01.5$ & $17.4 \pm 1.2$ & $3.98 \pm 0.11$ & $2.18 \pm 0.13$ \\
\hline $\mathrm{pH}$ & $6.54 \pm 0.5$ & $6.47 \pm 2.2$ & $8.50 \pm 0.05$ & $7.71 \pm 0.23$ \\
\hline Electrical conductivity $\left(25^{\circ} \mathrm{C}\right) \mathrm{dS} \mathrm{m}^{-1}$ & $2.59 \pm 0.86$ & $2.89 \pm 0.41$ & $8.62 \pm 0.07$ & $3.99 \pm 0.54$ \\
\hline Moisture\% & $8.12 \pm 0.15$ & $5.60 \pm 0.12$ & $51.53 \pm 1.25$ & $42,45 \pm 1.07$ \\
\hline
\end{tabular}

Values are the mean of two replicates corresponding to the 2 years \pm standard errors.

replicate plot, soil inoculated bags were buried at 15 and $30 \mathrm{~cm}$ soil depth.

Oospores of $P$. capsici were produced in vitro by pairing isolates of different mating types on soft pea agar following Núñez-Zofio (2011). Oospores embedded in nylon mesh were buried at 15 and $30 \mathrm{~cm}$ soil depth in three different points of each treatment replicate plot.

\section{Variables Measured}

- Ambient greenhouse temperature and soil temperatures in one replicate plot of each treatment at 15 and $30 \mathrm{~cm}$ depth were registered with 12-bit S-TMB-M017 temperature Hobo probes (accuracy $<0.2^{\circ} \mathrm{C}$ ) connected to an $\mathrm{H} 21-002$ Hobo datalogger. Readings were taken every $30 \mathrm{~min}$ throughout the biodisinfection treatment.

- Soil oxygen percentage content in one replicate plot of each treatment at $15 \mathrm{~cm}$ depth was registered with SO-200 galvanic cell type oxygen Apogee-Instruments probes (accuracy < $0.02 \% \mathrm{O}_{2}$ ) buried at a depth of $15 \mathrm{~cm}$ connected to an $\mathrm{H} 22$ 001 Hobo datalogger. Readings were taken every $30 \mathrm{~min}$ throughout the biodisinfection treatment.

- Viability of P. capsici oospores. First season. After 6 weeks of biodisinfection treatment, $P$. capsici oospore viability was determined using the plasmolysis method (Jiang and Erwin, 1990), adapted by Núñez-Zofio et al. (2013).

- Infectivity of P. capsici inoculum soil buried. Second season. After biodisinfection the bag with inoculated soil were removed, and the soil was placed in $150 \mathrm{~mL}$ pots into which "Lamuyo" cultivar (Clause Seeds) sensitive pepper plants were transplanted when they had four true leaves. The potted plants (three points for each treatment in each of the three replicate plots) were kept for 12 weeks in a chamber at $25^{\circ} \mathrm{C}$ and a relative humidity of $60-70 \%$ with $14: 10 \mathrm{~h}$ light: darkness of photoperiod and were kept. Notes were taken on the presence of yellowing, wilting or death once per week and those that presented symptoms were analyzed in PDA medium. As plants died, damaged tissue was washed with tap water and fragments of roots and crown were placed on potato dextrose agar and on PARPH (Jeffers and Martin, 1986) medium and incubated at $25^{\circ} \mathrm{C}$ for $4-6$ days. After that, the fungus was identified using microscopic observation. At the end of the bioassay, the plant roots were examined to detect symptoms of the disease. The results of infectivity were expressed as a percentage of diseased plants (Coelho et al., 2000; Lacasa et al., 2015).

- Marketable yield. Each 15 days, from April through to August in each season, the production of the plants was harvested and weighed separately for each treatment replicate plot. This variable was expressed in $\mathrm{kg} \mathrm{m}^{-2}$. Each replicate plot consisted of two rows and 45 plants were harvested from each row.

\section{Statistical Analysis}

The effects of treatments were studied using two way analysis of variance (ANOVA) with the Software Statgraphics Centurion 16. In order to fulfill the assumptions of analysis of variance (homocedasticity and normality), the infectivity bioassay data were transformed using $\operatorname{arcsine}(\sqrt{ } \mathrm{x} / \mathrm{n})$, where $\mathrm{x}=$ total number of dead plants and $n=$ total number of plants. Oospores viability data were transformed using arcsine $(\sqrt{ } \mathrm{x} / \mathrm{n})$, where $\mathrm{x}=$ total number of oospores survival and $n=$ total number of oospores. Data on crop yield were transformed using log transformation $\log (x+1)$, where $x=$ total yield. Means for significant main effects (biodisinfection treatment, soil depth) and all pairwise differences among least squares means within the biodisinfection treatment $\times$ soil depth interaction were separated by Fisher's LSD test $(p<0.05)$.

\section{RESULTS}

\section{Soil Temperatures}

Temperatures exceeding $38^{\circ} \mathrm{C}$ were reached in the amendments consisting of wheat husk+fresh sheep manure, in the sunflower pellets, and fresh sheep manure, at $15 \mathrm{~cm}$ in the first season. In the second season, although the largest number of hours was accumulated in the order of $33^{\circ} \mathrm{C}$, the soil was subjected to temperatures of up to $37^{\circ} \mathrm{C}$ for certain periods of time at both soil depths, 15 and $30 \mathrm{~cm}$. In the second season, the lowest number of accumulated hours above $33^{\circ} \mathrm{C}$ was found in the non-treated control. There were no temperatures exceeding $42^{\circ} \mathrm{C}$ in any of the treatments (Table 2). The mean ambient greenhouse temperature ranged from 13.6 to $31.8^{\circ} \mathrm{C}$ in the first season, and from 15.9 to $44.3^{\circ} \mathrm{C}$ in the second.

There was a period of anoxia during the biodisinfection process in both seasons in all the biodisinfection treatments (Figure 1). Variations were found among the treatments and 
TABLE 2 | Number of cumulative hours in each crop cycle at 15 and $30 \mathrm{~cm}$ soil depth within different temperature ranges.

\begin{tabular}{|c|c|c|c|c|c|}
\hline \multirow[b]{2}{*}{ Treatment } & \multirow[b]{2}{*}{ Depth (cm) } & \multicolumn{2}{|c|}{ First season } & \multicolumn{2}{|c|}{ Second season } \\
\hline & & $34-37^{\circ} \mathrm{C}$ & $38-41^{\circ} \mathrm{C}$ & $34-37^{\circ} \mathrm{C}$ & $38-41^{\circ} \mathrm{C}$ \\
\hline \multirow[t]{2}{*}{ Wheat husk + Fresh sheep manures } & 15 & 48 & 51 & 120 & 0 \\
\hline & 30 & 0 & 0 & 39 & 0 \\
\hline \multirow[t]{2}{*}{ Sunflower pellets } & 15 & 66 & 57 & 40 & 0 \\
\hline & 30 & 0 & 0 & 18 & 0 \\
\hline \multirow[t]{2}{*}{ Fresh sheep manures } & 15 & 60 & 52 & 223 & 0 \\
\hline & 30 & 0 & 0 & 147 & 0 \\
\hline \multirow[t]{2}{*}{ Control } & 15 & 0 & 0 & 30 & 0 \\
\hline & 30 & 0 & 0 & 0 & 0 \\
\hline
\end{tabular}

First and second season.

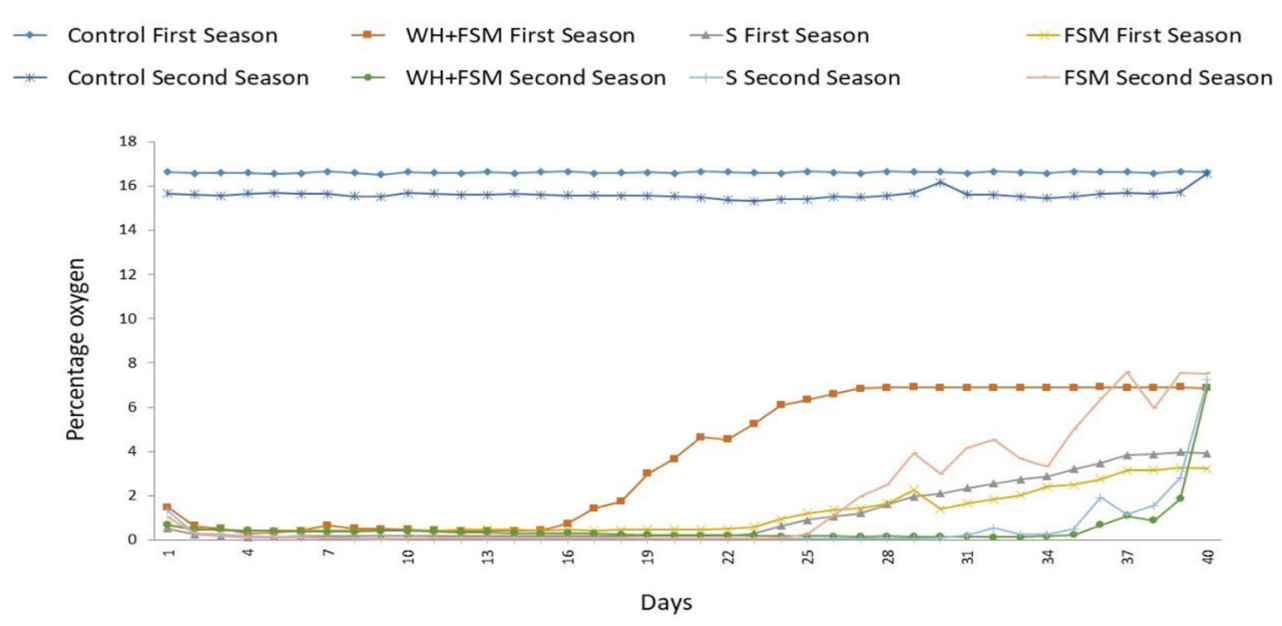

FIGURE 1 | Evolution of the percentage of oxygen in each treatment during the biodisinfestation process started in October at $15 \mathrm{~cm}$ depth. Abscisa axis: days from the start of the biodisinfestation. First and second seasons.

between years for the same treatment. In $\mathrm{WH}+\mathrm{FSM}$, at least $35.5 \%$ of the disinfestation time the $\mathrm{O}_{2}$ level was below $2 \%$ in the first year, whilst in the second year this was the case $84.4 \%$ of the time. In FSM at least $64.4 \%$ of the time the oxygen levels were below $2 \%$, whilst in the second year this occurred $57.7 \%$ of the time. In the first year the time that the oxygen level was below $2 \%$ in S and FSM was similar (at least 64.4\%) whilst in WH+FSM the figure was, of at least $35.5 \%$. In the second year, the oxygen level remained below $2 \%$ for $84.4 \%$ of the biodisinfection time in both $\mathrm{S}$ and $\mathrm{WH}+\mathrm{FSM}$, whilst in FSM the proportion of biodisinfection time with oxygen levels below $2 \%$ was at least $57.7 \%$.

\section{Effect of Treatments on P. capsici Oospore Viability}

\section{First Season}

Table 3 shows the viability of the oospores in each treatment and at each depth. The depth had an influence on oospore viability. At $15 \mathrm{~cm}$ the oospore viability was reduced in all the treatments, except for the control, while at $30 \mathrm{~cm}$ the reduction in viability was greater in the WH+FSM and S treatments than in the FSM. Biodisinfection reduced the viability of the oospores buried in the amendments with FSM as well as in those that did not contain it $\left[F_{(3,11)}=5.69 ; p=0.0028\right.$ at $15 \mathrm{~cm} ; F_{(3,11)}=2.92 ; p=0.004$ at $30 \mathrm{~cm}]$.

\section{Effect of Treatments on Infectivity of Introduced Soil Inoculum of $P$. capsici \\ Second Season}

The results obtained in the bioassay were different at $15 \mathrm{~cm}$ and $30 \mathrm{~cm}$ soil depth (Table 4). There were differences between the percentage of dead pepper plants in each treatment and the control at $15 \mathrm{~cm}$ (Table 4). The percentage of dead plants in the bioassay at $30 \mathrm{~cm}$ differed between the FSM and the control, although this was not the case for the other two amendments $\left[F_{(3,11)}=1.07 ; p=0.040\right.$ at $15 \mathrm{~cm} ; F_{(3,11)}=3.30 ; p=0.047$ at $30 \mathrm{~cm}$.

\section{Effect of Treatments on Marketable Yield}

Yields were significantly higher in the biodisinfested plots than in the control. The effect of biodisinfection treatments on marketable yield was significant in the first season $\left[F_{(3,15)}=\right.$ $4.16 ; p=0.009]$, and in the second season $\left[F_{(3,15)}=0.65 ; p=\right.$ 
TABLE 3 | Effect of biodisinfection treatments on $P$. capsici oospore viability percentage at two different soil depths $(15$ and $30 \mathrm{~cm}$ ) after 6 weeks of exposition.

\begin{tabular}{lcc}
\hline Biodisinfection treatment & $\mathbf{1 5} \mathbf{~ c m}$ & $\mathbf{3 0} \mathbf{~ c m}$ \\
\hline Wheat husk + Fresh sheep manure & $2.89 \pm 3.40 \mathrm{bA}$ & $3.34 \pm 2.23 \mathrm{bA}$ \\
Sunflower pellets & $4.46 \pm 4.93 \mathrm{bA}$ & $4.66 \pm 4.5 \mathrm{bA}$ \\
Fresh sheep manure & $3.29 \pm 2.91 \mathrm{bB}$ & $8.88 \pm 3.98 \mathrm{aA}$ \\
Control & $22.8 \pm 6.71 \mathrm{aA}$ & $5.11 \pm 2.85 \mathrm{abB}$
\end{tabular}

$x=$ mean percentage of viable oospores. Mean values $(n=12) \pm$ standard deviation. Data were transformed using arcsine $(\sqrt{ } x+0.5)$ where $x=$ mean percentage of viable oospores in each biodisinfection treatment at each soil depth.

The significant differences among biodisinfection treatments and each soil depth at 6 weeks were tested by two-way ANOVA.

Values in the same column followed by a different lower-case letter indicate significant differences between biodisinfection treatments within a given soil depth and upper-case letters compare soil depths for a given biodisinfection treatment based on the Fisher's LSD test $(p<0.05)$ within the interaction of biodisinfection and soil depth treatments. When differences were non-significant, letters were omitted.

TABLE 4 | Infectivity of introduced soil inoculum of Phytophthora capsici at 15 and $30 \mathrm{~cm}$ depth in bioassays with sweet pepper variety "Lamuyo" plants expressed as percentage of dead plants during bioassays in each treatment.

\begin{tabular}{lcc}
\hline Treatment & $\mathbf{1 5} \mathbf{~ c m}$ & $\mathbf{3 0} \mathbf{~ c m}$ \\
\hline Wheat husk + Fresh sheep manures & $77.7 \pm 12 \mathrm{a}$ & $77.7 \pm 12 \mathrm{ab}$ \\
Sunflower pellets & $77.7 \pm 19 \mathrm{a}$ & $88.9 \pm 19 \mathrm{ab}$ \\
Fresh sheep manures & $77.7 \pm 18 \mathrm{a}$ & $100.0 \pm 0 \mathrm{a}$ \\
Control & $44.4 \pm 19 \mathrm{~b}$ & $66.6 \pm 3 \mathrm{~b}$
\end{tabular}

Mean values $(n=12) \pm$ standard deviation. Data were transformed using arcsine $(\sqrt{ } x+0.5)$ where $x=$ mean percentage of lived plants at each soil depth

Values followed by the same letter are not significantly different according to Fisher's $L S D$ $(p<0.05)$.

TABLE 5 | Marketable yield $\left(\mathrm{kg} \mathrm{m}^{-2}\right)$ in each crop cycle.

\begin{tabular}{lll}
\hline Treatment & 1st season & 2nd season \\
\hline Wheat husk + Fresh sheep manures & $9.43 \pm 1.06 \mathrm{a}$ & $6.86 \pm 1.30 \mathrm{a}$ \\
Sunflower pellets & $9.72 \pm 1.79 \mathrm{a}$ & $6.96 \pm 0.80 \mathrm{a}$ \\
Fresh sheep manures & $9.21 \pm 1.17 \mathrm{a}$ & $6.30 \pm 1.20 \mathrm{a}$ \\
Control & $8.23 \pm 0.44 \mathrm{~b}$ & $5.00 \pm 0.39 \mathrm{~b}$ \\
\hline
\end{tabular}

Mean values $(n=4) \pm$ standard deviation. Data were transformed using log $(x+1)$, where $x=$ total yield. Values followed by the same letter are not significantly different according to Fisher's LSD $(p<0.05)$.

0.6028] (Table 5). The non-contribution of FSM had no negative influence on yield in the amendment composed of sunflower pellets. This fact increases the interest of the amendment, due to the situation of greenhouses in the zone subjected to restrictions in the $\mathrm{N}$ application with origin on livestock manures due to Nitrates Directive implementation.

\section{DISCUSSION}

In our trial, the temperatures obtained during the biodisinfection carried out in October with the amendments of wheat husk+fresh sheep manure, sunflower pellets, and fresh sheep manure exceeded $38^{\circ} \mathrm{C}$ in the first season, varying between 51 and $57 \mathrm{~h}$, but no in the second. At both seasons soil temperatures accumulated in October during the biodisinfection in the greenhouse were considerably lower than those obtained for the month of August in the same zone (Guerrero et al., 2019). Etxeberria et al. (2011) found that for $1,680 \mathrm{~h}$ at $15-35^{\circ} \mathrm{C}$, the survival of the oospores ranged between 88 and $36 \%$. The oospore viability in the two seasons was reduced by the presence of minimum temperatures above those reported by Etxeberria et al. (2011). The results also concur with those obtained by Lacasa et al. (2015) in which biodisinfection in spring with Sinapis alba fresh green manure did reduce the infectivity of Phytophthora nicotianae chlamydospores introduced inoculum (Gandariasbeitia et al., 2019). The infectivity of the surviving inoculum corresponded to an insufficient reduction of the inoculum buried in the bags. Coelho et al. (2000) considered that inoculum levels in excess of 1 propagule per gram of soil are necessary in order to detect the surviving inoculum using plant indicators in bioassays.

The biodisinfection with the assayed amendments induce anoxia in the soil for several weeks, which is one of the factors indicated for Gamliel et al. (2000) as cause of the decrease in the pathogen populations and of the efficacy of the disinfestation. In the first season, the level of oxygen in the soil was below $2 \%$ for more than $64 \%$ of the disinfestation time for S and FSM treatments, and over $35 \%$ of the time in WH + FSM. In the second season, the corresponding time was more than $57 \%$ in FSM and over $84 \%$ in S and for WH + FMS. The production of sporangia and the mycelial growth of several species of Phytophthora (including P. capsici) was considerably lower when the oxygen level was at $1 \%$ of oxygen in the crop solution. Below $2.5 \%$ of oxygen, the formation of sporangia is reduced and also the mycelial development of $P$. cinnamomi, affecting the viability of the inoculum (Davison and Tay, 1987).

The efficacy of the biodisinfection when temperatures are low improves with the contribution of amendments that are rich in organic matter or by increasing the amount of carbon

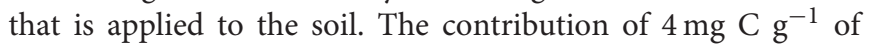
soil has been recommended to improve the efficacy of ASD at low temperatures (Butler et al., 2014; Rosskopf et al., 2015). It is recommended that the carbon of the organic amendment should be labile, so that it can easily and rapidly be degraded by the soil microorganisms and create conditions for persistent anaerobiosis. Additionally, an adequate ratio of $\mathrm{C} / \mathrm{N}$ must be considered so that, on the one hand, the $\mathrm{N}$ that is applied is enough so that $\mathrm{N}$ is not immobilized by the soil microorganisms in the degradation/mineralization of the organic amendments and, at the same time, there is not a potentially leachable excess of $\mathrm{N}$. In our trials, the amendments presented a balanced composition, and ratios of $\mathrm{C} / \mathrm{N}$ within the limits that are considered as adequate for biodisinfection and the generation of hypoxia.

The efficacy or failure of soil biodisinfection may be due to the soil characteristics, the degree of moistening, the electrical conductivity, the characteristics of the plastic, and the period of solarization (Chellemi, 2002). The temperate-humid climate has obstructed the application of biosolarization, very extended in 
Mediterranean horticultural areas such as South-eastern Spain. However, previous experimentation with different amendments, doses and application times compatible with crop cycles showed the applicability of these practices in the humid temperate climate region of Northern Spain (Ojinaga et al., 2020).

In the north of Spain, the survival of oospores of $P$. capsici was reduced at 15 and $30 \mathrm{~cm}$ when the biodisinfection was applied in August with both fresh and semi-composted manure (NúñezZofío et al., 2012). Using rice bran, rapeseed cake, or grape pomace as the carbon source, Serrano-Pérez et al. (2017) obtained significant reductions in chlamydospores viability and inoculum infectivity of pepper plants by $P$. nicotianae, when biodisinfection was carried out in low temperature open air conditions of the spring season in south western Spain.

Despite the low disinfectant efficacy assessed by the reduction in the survival of $P$. capsici oospores in sub-optimal conditions for solarization (absence of thermal inactivation), improvements were observed in the suppressiveness and in the chemical, physical and biological soil properties when the organic amendments were applied in biodisinfection, which caused a reduction of crop diseases and a yield increase (Núñez-Zofío et al., 2012; Rosskopf et al., 2015; Gandariasbeitia et al., 2019). It was concluded that repeated biodisinfection for the control of Phytophthora root and crown rot in protected pepper crops located in temperate climate regions can improve soil quality and suppressiveness, as well as enabling reduced doses of the organic amendment needed for biodisinfection. However, this disinfestant efficacy worsened when the biodisinfection was performed in March (Arriaga et al., 2011), and also when it was carried out in September (Núñez-Zofío et al., 2011).

One strategy employed when biodisinfection fails due to the climate or crop cycles is to turn to anaerobic disinfection. This strategy has been applied in limiting solarization conditions in Japan (Shinmura, 2000; Momma et al., 2005, 2006, 2010, 2011; Katase et al., 2009) and also in the Netherlands (Blok et al., 2000; Agtmaal et al., 2015).

The effect of the application of organic matter produced a yield increase in both seasons. Although there was no naturally occurring presence of pathogens, the increased yield in the biodisinfested plots might be explained by the reduction of soil fatigue in the crop. The fatigue accumulated in greenhouses used for pepper monocropping is highly specific toward pepper (Guerrero et al., 2014). The greenhouse assayed in this study fits the conditions of pepper monocropping. Biodisinfection with fresh sheep manure of greenhouses used to grow pepper crops, improved the physical and chemical characteristics of the soil (Fernández et al., 2005). The application of wood waste and sunflower husk biochar improved soil porosity and the structural stability of soil aggregates (Sokołowska et al., 2020). Improvement of soil water infiltration, soil drainage, and roots aeration have been associated with a better control of crop root rot caused by soilborne pathogenic species of Phytophthora (Ristaino, 1991).
The principal cause of this fatigue is considered to be biotic and related with the extent to which the soils are contaminated with Fusarium sp. (Martínez et al., 2009, 2011). It is additionally known that the fatigue accumulated in greenhouses used for pepper monocropping is highly specific toward pepper (Guerrero et al., 2014). In soils contaminated by Fusarium spp. and Phytophthora spp., Song et al. (2020a,b) obtained a significant reduction in the incidence of Fusarium and Phytophthora in strawberry crops in conditions of biodisinfection with chicken manure or with maltose as carbon sources at $28^{\circ} \mathrm{C}$ and covering the soil with total impermeable film. They also observed a yield improvement related with the increase of soil available nutrients after the biodisinfection treatment.

In those plots where FSM was not used in this study, the yields were similar to those in which it had been used. This fact is of great interest since the cropping zone of Southeast Spain is subject to organic matter restrictions. Moreover, it is known that the incorporation of organic correctives improves soil properties and fertility, as reported by Bonanomi et al. (2007).

The results obtained with the carbon-rich and balanced amendments and in time periods that are compatible with the pepper crop cycle in greenhouses in southeast Spain, showed a yield improvement. This increased yield may also be due to the effect highlighted by Núñez-Zofío et al. (2011) that repeated biodisinfection treatments in temperate climate areas improve soil suppressiveness and quality. This would enable growers to extend the crop cycle and thereby the corresponding economic benefit.

In conclusion, using the specific organic amendments, significant reductions were obtained in the viability of the inoculum resting structures of $P$. capsici as well as increases in the marketable yield, when biodisinfection is performed on dates that are compatible with the pepper growing cycle in the Campo de Cartagena. This way of soil disinfestation is recommendable in the context of the strategies of sustainable integrated production.

\section{DATA AVAILABILITY STATEMENT}

The original contributions presented in the study are included in the article/supplementary material, further inquiries can be directed to the corresponding author/s.

\section{AUTHOR CONTRIBUTIONS}

MG designed the experiment and wrote the original draft. CL, VM, MM, and AM supervised the experiment and contributed to the data. SL revised the manuscript. All authors approved the submitted version.

\section{FUNDING}

This work has been supported by project FEDER1420-31. 


\section{REFERENCES}

Agtmaal, M., Os, G. J., Gera Hol, W. H., Hundscheid, M. P. J., Runia, W. T., et al. (2015). Legacy effects of anaerobic soil disinfestation on soil bacterial community composition and production of pathogensuppressing volatiles. Front. Microbiol. 6:701. doi: 10.3389/fmicb.2015.00701

Arriaga, H., Núñez-Zofío, M., Larregla, S., and Merino, P. (2011). Gaseous emissions from soil biodisinfection by animal manure on a greenhouse pepper crop. Crop Prot. 30, 412-419. doi: 10.1016/j.cropro.2010. 12.012

Blaya, J., Lacasa, C. M., Lacasa, A., and Pascual, J. A. (2014). Characterization of Phytophthora nicotianae isolates in south-east Spain and their detection and quantification through a real-time TaqMan PCR. J. Sci. Food Agric. 95, 1243-1251. doi: 10.1002/jsfa.6813

Blok, W. J., Lamers, J. G., Termorshuizen, J., and Bollen, G. J. (2000). Control of soilborne plant pathogens by incorporating fresh organic amendments followed by tarping. Phytopathology 90, 253-259. doi: 10.1094/PHYTO.2000.90.3.253

Bonanomi, G., Antignani, V., Pane, C., and Scala, F. (2007). Suppression of soilborne fungal diseases with organic amendments. J. Plant Pathol. 89, 311-324. https://www.jstor.org/stable/41998410

Butler, D. M., Kokalis-Burelle, N., Albano, J. P., McCollum, T. G., Muramoto, J., Shennan, C., et al. (2014). Anaerobic soil disinfestation (ASD) combined with soil solarization as a methyl bromide alternative: vegetable crop performance and soil nutrient dynamics. Plant Soil 378, 365-381. doi: $10.1007 /$ s11104-014-2030-z

Butler, D. M., Kokalis-Burelle, N., Muramoto, J., Shennan, C., McCollum, T. G., and Rosskopf, E. N. (2012). Impact of anaerobic soil disinfestation combined with soil solarization on plant-parasitic nematodes and introduced inoculum of soilborne plant pathogens in raised-bed vegetable production. Crop Prot. 39, 33-40. doi: 10.1016/j.cropro.2012.03.019

Chellemi, D. O. (2002). Nonchemical management of soilborne pests in fresh market vegetable production systems. Phytopathology 92, 1367-1372. doi: 10.1094/PHYTO.2002.92.12.1367

Coelho, L., Mitchell, D. J., and Chellemi, D. O. (2000). Thermal inactivation of Phytophthora nicotianae. Phytopathology 90, 1089-1097. doi: 10.1094/PHYTO.2000.90.10.1089

Davison, E. M., and Tay, F. C. S. (1987). The effect of waterlogging on infection of Eucalyptus marginata seedlings by Phytophthora cinnamomi. New Phytol. 105, 585-594. doi: 10.1111/j.1469-8137.1987.tb00896.x

Erwin, D. C., and Ribeiro, O. K. (1996). "Morphology and identification of Phytophthora species," in Phytophthora Diseases Worldwide, eds D. C. Erwin and O. K. Ribeiro (Saint Paul, MN: American Phytopathological Society Press), 96-144.

Etxeberria, A., Mendarte, S., and Larregla, S. (2011). Thermal inactivation of Phytophthora capsici oospores. Rev. Iberoam Micol. 28, 83-90. doi: 10.1016/j.riam.2011.01.004

Fernández, P., Guerrero, M. M., Martínez, M. A., Ros, C., Lacasa, A., and Bello, A. (2005). "Effects of biofumigation plus solarization on soil fertility. Industrial crops and rural development," in Proceedings of the Annual Meeting Association for the Advancement of Industrial Crops 17-21 September (Murcia), 229-336.

Gamliel, A., Austerweil, M., and Kitzman, G. (2000). Non chemical approach to soilborne pest management organic amendments. Crop Prot. 19, 847-853. doi: 10.1016/S0261-2194(00)00112-5

Gandariasbeitia, M., Ojinaga, M., Orbegozo, E., Ortiz, A., Nuñez-Zofío, M., Mendarte, S., et al. (2019). Winter biodisinfestation with Brassica green manure is a promising management strategy for Phytophthora capsici control of protected pepper crops in humid temperate climate regions of Northern Spain. Span. J. Agric. Res. 17:e1005. doi: 10.5424/sjar/2019171-13808

Guerrero, M., Lacasa, C. M., Martínez, V.,Martínez-Lluch, M. C., Larregla, S., and Lacasa, A. (2019). Soil biosolarization for Verticillium dahliae and Rhizoctonia solani control in artichoke crops in southeastern Spain. Span. J. Agric. Res 17:e1002. doi: 10.5424/sjar/2019171-13666

Guerrero, M. M., Guirao, P., Martínez, M. C., Tello, J. C., and Lacasa, A. (2014). Soil fatigue and its specificity towards pepper plants in greenhouses. Span. J. Agric. Res. 12, 644-652. doi: 10.5424/sjar/2014123-5701

Guerrero, M. M., Lacasa, C. M., Hernández, A., Martínez, V., and Lacasa, A. (2013). Evaluation of repeated biodisinfestation using Brassica carinata pellets to control Meloidogyne incognita in protected pepper crops. Span. J. Agric. Res. 11, 485-493. doi: 10.5424/sjar/2013112-3275

Guerrero, M. M., Ros, C., Lacasa, C. M., Martínez, V., Lacasa, A., and Fernández, P., et al. (2010). Effect of biosolarization using pellets of Brassica carinata on soilborne pathogens in protected pepper crops. Acta Hortic. 883, 337-334. doi: 10.17660/ActaHortic.2010.883.42

Jeffers, S. N., and Martin, S. B. (1986). Comparison of two media selective for Phytophthora and Pythium species. Plant Dis. 70, 1038-1043. doi: 10.1094/PD-70-1038

Jiang, J., and Erwin, D. C. (1990). Morphology, plasmolysis and tetrazolium bromide stainas criteria for determining viability of Phytophthora oospores. Mycologia 82, 107-113. doi: 10.1080/00275514.1990.12025847

Katan, J. (2005). Soil disinfestation: one minute before Methyl Bromide phase out. Procedures of VIth International Symposium on Chemical and Non-Chemical Soil and Substrate Disinfestation. Acta Hortic. 698, 19-25. doi: 10.17660/ActaHortic.2005.698.1

Katase, M., Kubo, C., Ushio, S., Ootsuka, E., Takeuchi, T., and Mizukubo, T. (2009). Nematicidal activity of volatile fatty acids generated from wheat bran in reductive soil disinfestation. Jpn. J. Nematol. 39, 53-62. doi: 10.3725/jjn.39.53

Lacasa, C. M., Guerrero, M. M., Ros, C., Martínez, V., Lacasa, A., Fernández, P., et al. (2010). Efficacy of biosolarization with sugar beet vinasses for soil disinfestation in pepper greenhouses. Acta Hortic. 883, 345-352. doi: 10.17660/ActaHortic.2010.883.43

Lacasa, C. M., Martínez, V., Hernández, A., Ros, C., Lacasa, A., and Guerrero, M. M. (2015). Surival reduction of Phytophthora capsici oospores and P. nicotianae chlamydospores with Brassica green manures combined with solarization. Sci Hortic. 197, 07-618. doi: 10.1016/j.scienta.2015.10.024

Lacasa, C. M., Martínez, V., Martínez, M. C., Lacasa, A., and Tello, J. (2013). Phytophthora en los invernaderos de pimiento del Campo de Cartagena (Murcia) Agroecologia 12, 18-19.

Martínez, M. A., Lacasa, A., and Tello, J. (2009). Ecología de la Microbiota Fúngica de los Suelos de los Invernaderos de Pimiento y su Interés Agronómico. Ministerio de Medio Ambiente, Medio Rural y Marino, Madrid. ISBN: 978-84-491-0987-4.

Martínez, M. A., Martínez, M. C., Bielza, P., Tello, J., and Lacasa, A. (2011). Effect of biofumigation with manure amendments and repeated biosolarization on Fusarium densities in pepper crops. J. Indust. Microbiol. Biotechnol. 38, 3-11. doi: 10.1007/s10295-010-0826-2

Mazzola, M. (2011). "Potential of biofumigation of soilborne pest control in strawberry," in Proceedings of Annual International Research Conference on Methyl Bromide Alternatives and Emissions Reductions (San Diego, CA), 41-47.

Mazzola, M., and Manici, L. M. (2012). Apple replant disease: role of microbial ecology in cause and control. Annu. Rev. Phytopathol. 50, 45-65. doi: 10.1146/annurev-phyto-081211-173005

Mazzola, M., Shennan, C., and Muramoto, J. (2012). "Application sequence and soil biology influence anaerobic soil disinfestation induced disease suppression," in Proceedings of the 2012 Annual International Research Conference on Methyl Bromide Alternatives and Emissions Reductions (Orlando) 57, 1-3.

Momma, N., Kobara, Y., and Momma, M. (2011). Fe2+ and Mn2+, potential agents to induce suppression of Fusarium oxysporum for biological soil disinfestation. J. Gen. Plant Pathol. 77, 331-335. doi: 10.1007/s10327-011-0336-8

Momma, N., Momma, M., and Kobara, Y. (2010). Biological soil disinfestation using ethanol: effect on Fusarium oxysporum f. $\mathrm{sp}$. lycopersici and soil microorganisms. J. Gen. Plant Pathol. 76, 336-344. doi: 10.1007/s10327-010-0252-3

Momma, N., Usami, T., Amemiya, Y., and Shishido, M. (2005). Factors involved in the suppression of Fusarium oxysporum f. sp. lycopersici by soil reduction. Soil Microorg. 59, 27-33. doi: 10.18946/jssm.59.1_27

Momma, N., Yamamoto, K., Simandi, P., and Shishido, M. (2006). Role of organic acids in the mechanisms of biological soil disinfestation (BSD). J. Gen. Plant Pathol. 72, 247-252. doi: 10.1007/s10327-006-0274-z

Núñez-Zofio, M. (2011). Evaluación de la biodesinfección para el control de Phytophthora capsici en el cultivo de pimiento en invernadero (Tesis doctoral). Universidad del País Vasco - Euskal Herriko Unibertsitatea, España, 305.

Núñez-Zofío, M., Larregla, S., and Garbisu, C. (2011). Application of organic amendments followed by soil plastic mulching reduces the incidence of 
Phytophthora capsici in pepper crops under temperate climate. Crop Prot. 30, 1563-1572. doi: 10.1016/j.cropro.2011.08.020

Núñez-Zofío, M., Larregla, S., and Garbisu, C. (2012). Repeated biodisinfection controls the incidence of Phytophthora root and crown rot of pepper while improving soil quality. Span. J. Agric. Res. 10, 794-805. doi: 10.5424/sjar/2012103-571-11

Núñez-Zofio, M., Larregla, S., Garbisu, C., Guerrero, M. M., Lacasa, C. M., and Lacasa, A. (2013). Application of sugar beet vinasse followed by solarization reduces the incidence of Meloidogyne incognita in pepper crops while improving soilquality. Phytoparasitica 41, 181-191. doi: 10.1007/s12600-012-0277-6

Ojinaga, M., Gandariasbeitia, M., Orbegozo, E., Ortíz, A., Guerrero, M. M., Lacasa, C. M., et al. (2020). Biodisinfestation for Meloidogyne and Verticillium control in commercial protected crops in the Basque Country Atlantic area (northern Spain). Acta Hortic. 1270, 327-336. doi: 10.17660/ActaHortic.2020.1270.40

Oka, Y. (2010). Mechanisms of nematode suppression by organic soil amendments: a review. Appl. Soil Ecol. 44, 101-115. doi: 10.1016/j.apsoil.2009.11.003

Ristaino, J. B. (1991). Influence of rainfall, drip irrigation, and inoculum density on the development of Phytophthora root and crown rot epidemics and yield in bell pepper. Am. Phytopathol. Soc. 81:922.

Rosskopf, E. N., Serrano-Pérez, P., Hong, J., Shrestha, U., Rodríguez-Molina, M. C., Martin, K., et al. (2015). "Anaerobic soil disinfestation and soilborne pest management," in Organic Amendments and Soil Suppressiveness in Plant Disease Management, eds M. Meghvansi and A. Varma (Cham: Springer), 277-305.

Serrano-Pérez, P., Rosskopf, E., De Santiago, A., and del Carmen RodríguezMolina, M. (2017). Anaerobic soil disinfestation reduces survival and infectivity of Phytophthora nicotianae chlamydospores in pepper. Sci. Hortic. 215, 38-48. doi: 10.1016/j.scienta.2016.12.003

Shennan, C., Mazzola, M., Rosskopf, E. N., Kokalis-Burelle, N., Momma, N., Butler, D. M., et al. (2014). Anaerobic soil disinfestation for soil borne disease control in strawberry and vegetable systems: current knowledge and future directions. VIII Int. Symp. Chem. Non Chem. Soil Subst. Disinfest 1044, 165-175. doi: 10.17660/ActaHortic.2014.1044.20

Shinmura, A. (2000). Causal agent and control of root rot of Welsh onion. PSJ Soilborne Dis.Workshop Rep. 20, 133-143.

Sokołowska, Z., Szewczuk-Karpisz, K., Turski, M., Tomczyk, A., Cybulak, M., and Skic, K. (2020). Effect of wood waste and sunflower husk biochar on tensile strength and porosity of dystric Cambisol artificial aggregates. Agronomy 10:244. doi: 10.3390/agronomy10020 244

Song, Z., Massart, S., Yan, D., Cheng, H., Eck, M., Berhal, C., et al. (2020a). Composted chicken manure for anaerobic soil disinfestation increased the strawberry yield and shifted the soil microbial communities. Sustainability 12:6313. doi: $10.3390 /$ su12166313

Song, Z., Yan, D., Fang, W., Huang, B., Wang, X., Zhang, D., et al. (2020b). Maltose and totally impermeable film enhanced suppression of anaerobic soil disinfestation on soilborne pathogens and increased strawberry yield. Sustainability 12:5456. doi: 10.3390/su12135456

Conflict of Interest: The authors declare that the research was conducted in the absence of any commercial or financial relationships that could be construed as a potential conflict of interest.

Copyright $\odot 2021$ Guerrero, Lacasa, Martínez, Martínez, Monserrat and Larregla. This is an open-access article distributed under the terms of the Creative Commons Attribution License (CC BY). The use, distribution or reproduction in other forums is permitted, provided the original author(s) and the copyright owner(s) are credited and that the original publication in this journal is cited, in accordance with accepted academic practice. No use, distribution or reproduction is permitted which does not comply with these terms. 